\title{
The Impact of Photographic Images in Print and Online Media for Political Campaign in Malaysia
}

\author{
Md. Nagib Padil and Mustaffa Halabi Azahari
}

\begin{abstract}
Photography is one of the popular medium in use by the mass media either electronic or print media in any activities election campaign. In winning the heart of voters, politician's party use photographic images as main communication strategies in delivering their messages, agendas and also to catch the voter's attention. As for voters, they need the required information as their reference before making any decisions. Regarding this, the present of the proposal paper is to identify to what extent the role of the photographic image presented in traditional newspaper and online media as serve as a vehicle in persuasion strategy and the impact on perception in the eyes of the voters that changes the pattern political landscape in Malaysia.
\end{abstract}

Index Terms-Political campaign, photographic images, print and online.

\section{INTRODUCTION}

Malaysia is one of the countries that practices parliamentary democracy rule. With reference to Article 113 (1) of the Federal Constitution, elections allow the principle of freedom for a citizen to voice out their hopes and choose their own leader who will speak out for their rights. Voters are also the determinants towards the victory of any election, whereas political parties will fight for votes via campaigning tactics to influence and persuade voters to vote for them. [1] General election is a significant event for the ruling power, as any decision made will determine the citizen's future from all walks of life. Referring to Oxford dictionary, election is defined as "the process of choosing a person or a group of people for a position, especially a political position, by voting".

Communication delivery is also significant in relaying messages to the community, which is evident from the past general elections - since the first general election in 1955 up to the $13^{\text {th }}$ general election on April 3, 2013 under the leadership of Dato Seri Najib Tun Razak. The pattern of message delivery showed a great impact on the community, apart from bringing forth a great impact on the political system in Malaysia [2]. According to Michael C. Leemay (2002), elections are often associated with ' $3 \mathrm{M}$ ', which is very popular and significant in any election campaign, either in developed or developing countries that refers to 'Media, Money and Machinery' [3].

To obtain absolute victory, political parties often resort to communication strategies that revolve around print and electronic media in efforts to influence the voters to sway

Manuscript received July 20, 2013; revised September 22, 2013.

Md. Nagib Padil is with the Art And Design, University Technology Mara, Shah Alam, Selangor, Malaysia (e-mail: tourismo_1@yahoo.com). their votes. Apart from verbal communication such as public debates or speeches, electronic media such as radio, television, video, internet, and also the print media such as newspapers, flyers, banners and posters are regarded as an independent broker of information. [4] Refer to Shanto Iyengar (2011:p191), Media-based campaigns take place on two stages: free media (news coverage) and paid media (candidate advertisement). However he argues that media, taking on the role as a medium campaign channel, brings a great impact on the community as it influences their minds and perspectives on arising problems in the country (agenda setting) whilst shifting citizens' take on public issues (framing), altering the criteria by which voters make their choices (priming), whereas the evidence demonstrated considerable changes in public sentiment (persuasion) ( $\mathrm{p}$ : 13).

As a medium of modern election information source, apart from element text, illustration, cartoons etc, the use of images in the media such as in newspapers or internet campaigning based also is found as one of the strategy that help to ensure the victory of any party in election campaign. The advantages not just opportunity to tell their stories and bring a great impact on the readers in the context of knowledge (factual information) or emotional responses, but is also powerful easy to use for the purposed of influencing people's attitudes, opinion and beliefs.

\section{LITERATURE}

More than 150 years since its introduction to the world in 1826, photography has been utilized across a wide range of print, electronic and other forms of media such as in advertising and commercial, video and film-making, fine art photography, portraiture and journalistic form [5]. Photography image plays a very significant role in our daily lives. It's apparent that photographic images are widely used as the main medium in presentation such as billboard advertisements, illustrated magazines, newspapers, television and also the Internet. Refer to Mustaffa Halabi (2011), he explained every image delivers its message with different purposes such as to inform, educate, promote, entertain and persuade. Images are extensively deployed and employed for a variety of purposes and intended effects in a wide range of communication and leisure industries.

Mustaffa Halabi also stated that the significance of photography has to be considered within two main stands. The first is the nature of photography as realistic forms of representation and the second is its representation that's similar to the linguistic analogy, with its own codes and conventions or as mirror representation or interpretation [6], 
in another words, the reproduction copying of object or character appears in the photograph represent reality (similar) and truly experience.

In winning the hearts of voters, photographic images are used as a technique of mass persuasion in any political campaigns, especially in print media such as newspapers, as it is one of the most popular methods used in delivering their agendas and also to catch the audience's attention. From Joffes (2008) point of view, photographic images that are displayed in newspapers can influence the audience's emotions more effectively apart from text materials that leave them in a more rational, logical and liner pathway of thought [7]. Elsewhere, Lester (2003) has his own view and he describes that visual images are a powerful form of communication as they stimulate both intellectual and emotional responses [8].

Apart from the traditional newspaper, photographic image also plays an important role in the online newspaper or web site. Cyber campaign that was launched by the individual bogglers or political parties on the Internet such as Malaysia Today, Malaysia Kini, etc. or sharing through social networking sites such as Facebook, Twitter and Youtube have given brand-new politician platforms and provided the individual user with easy access to unlimited audience. The potential impact of new media in see have a power to political organization to recruit and mobilize individual and accomplish multiple campaign objective. As party-based campaigns were replaced by media-based campaign, online media see as an independent channel for political party to speak out and share information to public directly [9]. Refer to Shanto Iyengar (2011) is also used by the public for evaluating issues and visual image presented by the printed media and electronic media and greatly enhanced form of participation to young people engaged in political activity (pp: 120-128).

In Malaysia, based in the past election, has found the medium photography through media campaign is one of the factor that changed the pattern of political landscape, it is not just used as news and information campaign, it was able to create awareness among the voters to choose a party with more transparent. According to Shanto Iyengar (2011), the news media focuses on the use of photographic images for the campaign into two fractions. First, image ads - maintain thematic continuity with biographical messages by presenting the candidate as a likable human being with a strong sense of public service. Second, issue ads - more substantive and either focusing on the candidate's past experience and record in public life or outlines position on major policy issues (pp: 164).

Referring to the advantages of photographic images to the news media in any election campaigns, Syed Arabi (1993) said that photographic images could portray better stories and news, rather than words alone. The photographic images used in visual presentations in the media will become long lasting memories with the power to change a listener or viewers' attitude [10]. Meanwhile, Teryy Barrett (2006) stated photographic images can exert a positioning power on the viewers' imagination. Even without words, a well-constructed photograph can create a creative and logical storytelling that grabs the viewer attention [11].
As in anthropology studies medium photography is not only seen as a factual aspect but also shares in the aspects of value. Through observation, it is also found that persuadable voters share information, knowledge and emotional reactions on how certain subgroups think about candidates or party [12]. Photography images are also considered as one of the media with the most potential to build a symbolic identity of the party, in which, the images help enhance the candidate's familiarity and personal quality to voters. The images also help to develop a message that appeals to the targeted audience, whilst understanding the issues that are important to the potential voters in the state.

\section{BACKGROUND PROBLEMS}

In Malaysia, based on several studies of past election results, the role of the mass media have been found to have a significant impact on the party's credibility and performance. Refer from Syed Arabi (2011) from his point of view, the influence of this institution he said to be effective as determinants on the rise or fall of a leader and political parties in Malaysia [13].

As instrument election campaign, print media especially the mainstream media have been found to use the medium of photography as a report in favour of certain parties and not presenting balanced information and news. This has led to alternative media such as online media or social media that voters have turned to as a new form of communication to get the latest information and news on Malaysian politics.

Apart from the text, photographic images are the relevant methods used in evidence in receiving and analyzing information in the media. The use of photographic images as a campaign strategy that describes and explains the issues, the candidates and the election should be accurate and balanced to ensure that it provides a big impact on voters. Accuracy of image selection and disclosure to the public should be a priority to create a positive perception and influencing their minds about this. According to Nathaniel Swigger (2009), the process of persuasion need to change the attitude of an image, and the image has always been the surest way to convey ideas [14].

The functional aspects of photographic images especially in newspaper content, as a source reporting on political information is not mainly a simple picture snapshot used to highlight a story, sometimes it must be used as a mode of storytelling, ideas and value systems of their views.

Understanding the part of a special image is important because of the role these images play in the political campaign process. They can affect not only how people vote, but whether they can choose to engage in a political process.

Apart from imparting visual messages that lingers in the mind of readers as a reference of memory literature, messages must be able to send a language that is easy understand by the audience and not misleading. Messages should contain package imagery and technical elements that can be used as 'deliver clues' by readers in understanding and evaluating visual information that are published, no matter whether it is the truth or manipulated by certain parties

Issues on image manipulation contained in the online media and print media are used as a strategy of persuasion or 
political rhetoric must be taken seriously to improve the credibility of news sources to meet needs in the context of a democratic society to generate, the election campaign is well and free and transparent.

Based on these factors, this study wanted to see and understanding the part of a special image, technique and an important the mode of storytelling in print and online campaigning as a key to explain an issues, candidates and ideology to voter effectively in a political process.

\section{RESEARCH OBJECTIVE}

To achieve the objective of the research, researcher will study the role of images in the newspaper and online news its impact on the readers, and thus, researcher will outline three objectives, which will be the main course of this research, namely;

1) To examine various images in the Malaysian printed newspaper and online media those are related to election campaigns (GE-11, GE-12 and 2013).

2) To study the importance effect and impact of images be used as a reference by the news media in enhanced message effectiveness on readers.

3) To provide appropriates guidelines, which can be used for Politicians, Printed and Electronic Media Personnel (Editors, Reporters and Photography Practitioners), Academicians, Students as well as others who have interest in media practice.

\section{OUTCOME RESEARCH/SIGNIFICANCE RESEARCH}

The outcome of this research is to provide a sound advice to the Malaysian media industry on the ideas and strategies to represent the right approach for news photographs with the inclusion of accurate news, notoriety and actions, and also on presenting images that reflect our society. A new constitutional settlement by communication reforms of the mass communication media must be reflected by addressing the process of collaboration between the media and the audience, ultimately helps create a better story in the public service media.

The research outcome can also be used as a reference by the news media, photographers and blogger's in Malaysia, in order for them to be more sensitive on the content usage and delivery of messages that uses the platform of photographic images as the major news of information for the society. The messages should be precise, transparent, and understandable and can be evaluated by the readers to avoid the messages to be misinterpreted and manipulated by irresponsible parties. Thus, it can further instil one's trust on the role of photographic images in a reliable and independent media, especially for campaigning activities in the elections in the near future.

It is also hoped that this study can provide a huge contribution as a main guideline to the government, foreign media, internal media associations, academicians, art or media students and researchers who are interested in conducting research on the role of photographic images for the purpose of election campaigning in the newspapers and online media in Malaysia.

\section{Methodology}

This research will involve qualitative method approach activities (primary data) to meet and obtain product information for maximum results. [15] As emphasised by Mason that qualitative research enables research to explore a "wide arrange of dimension of the social world, including the texture and wave of everyday life, the understandings, experience and imagining of our research participants, the way that social process, institutions, discourses or relationship work, and the significance of the meanings that generate" (cited, Mustaffa Halabi, 2006).

\section{A. Collection of Related Materials}

The collection of photographic images, captions, texts, and related elections documents of GE11 in 2004, GE12 in 2008 and GE 12 in 2013. All these will be carried out at the Arkib Negara (National Archives of Malaysia), Malaysia National Library, various newspapers archives and Internet such as blogs, social media.

Research focus and resources are as follows;

Printed Newspaper: Utusan Malaysai, Berita Harian, New Straits Times, Malay Mail, Suara Keadilan, Harakah (2004-2013), Harian Metro, Chiness Press, Harian Tamil Malaysia Nanban (2013) and Tamil Nelsan Daily.

Online news: Individual Bolgs and Facebook

\section{B. Observation/Contents Analysis}

In addition to that, the clippings will be analyzed by researcher for a better understanding on the style of presentation, frequency and technical aspects of the photography used on the images during the campaigning activities.

\section{MAPPING AND ANALYSIS}

\section{A. Subject Matter}

\section{1) Describing subject matter in print media}

Subject matter use for content print media more emphasis on quality, integrity and full fill the public trust (See Fig. 1). They also provide an important endorsement demanded function as a vehicle for campaigning.

Study also found the subject matter was more effective in formal presentation to response the visual credibility or fact.

Technical features of campaigning for subject matter are distress direct or indirectly (abstract) use to send the message or inform to the readers.

Pictures message expressing and sharing views, opinions, and ideas operative likes thinking, remembering and judgment.

Focuses of subject matter related to a variety of topics likes personalities, ideological on leader, issues in effected to support the favorable group and parties team in updating the knowledge of specific type of audiences.

\section{2) Describing subject matter in online media}

Source of subject matter from blog or online media space 
more to individual ownership. More subject recorded produce by armature journalist or photographer and among party supporter. Focuses of the subject are more opinion information.

Fresh approach to the subject matter in promoting stories based on interest like popularity of leaders or candidates (portrait and lifestyle) allow the medium used to compare and bringing transparency to parties' issues clearly.

Study also founds, reported of subject matter from online media was limited use in convey the message contents. People are learning a basis subject on simply and straightforward photo. Coping image strategies and extreme big bold headline (text messages) are use in discusses fit with activities and issues for campaign imagery.

Made in an artistic way and beautiful and maximum sensitive issues of subject matter on the web page, a popular of strategies and tactics to make the pages to be read favorable and without being bored (See Fig. 2).

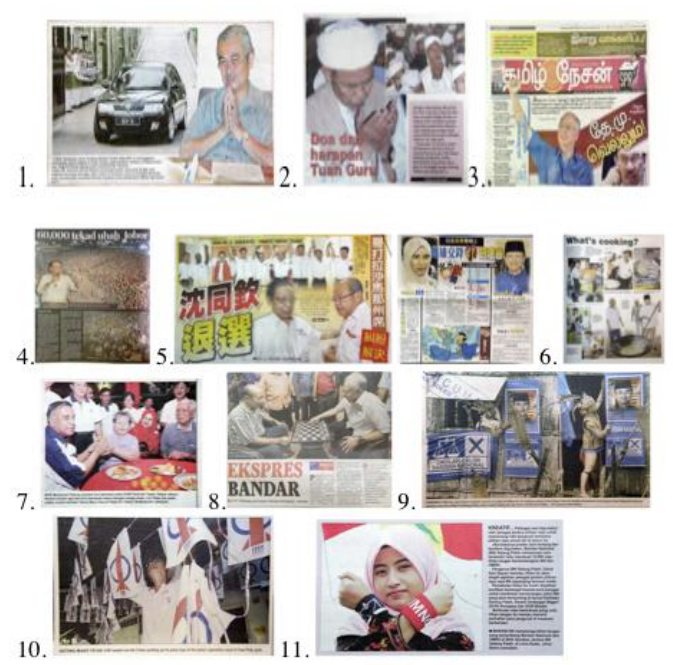

Source: 1.Utusan Malaysia 4 March 2004, 2 Harakah 14-16 March 2004, 3. Tamil Nelsan Daily 5 Mei 2013, 4. Suara Keadilan 3 Mei 2013, 5. China Press 23 April 20136.The Malay Mail 7 March 2008,7. Utusan Malaysia 28 February 2008, 8. Harian Metro 12 April 2013, 9. New Straits Times 9 March 2004, 10. News Straits Times 6 March 2004, 11. Utusan Malaysia 16 February 2008.

Fig. 1. Subject matter: leaders, candidates and supporter.

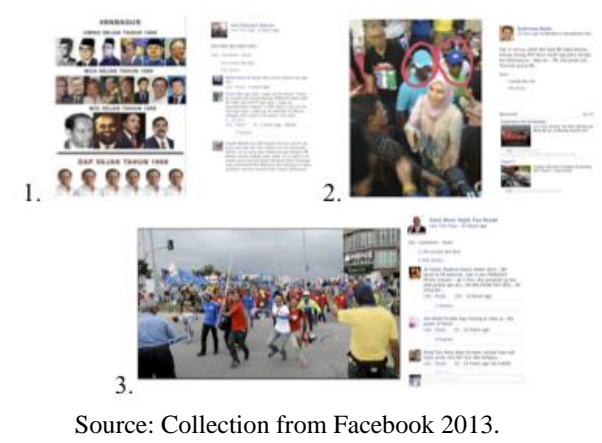

Fig. 2. Subject matter: leaders, candidates and supporter.

\section{B. Form}

\section{1) Describing form in newspaper}

On form study, mostly the importance and big issues reporting in newspaper will present in colour compare to unimportance issues. Positioning an object at top of a spread and giving the object a bigger size could lead to reader seeing it early.

Some news campaign represented to the viewer by his visual experience. The idea of symbolic form can use in expresses their point of view and meaning. A creative of clue structure on a picture's surface such as elements line, texture, space etc. easier defined as a mark in explaining issues or to address the topic covering. It also provides their intentions beliefs, experiences and emotions.

Most effective use of light, motion, and repetition to creates interest and uniqueness of activities campaign.

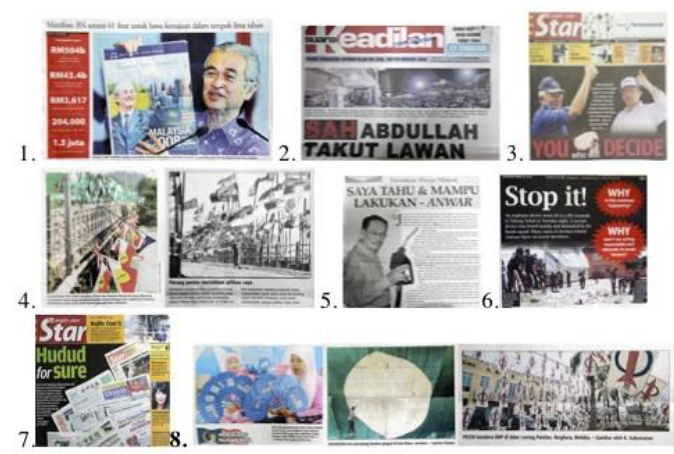

Source: 1. Berita Harian 26 February 2008, 2. Suara Keadilan 14-27 February 2008, 3 The Star 4 Mei 2013,4.Berita Harian 19 February 2008, 5. Suara Keadilan 27 February-12 March 2008, 6. The Malay Mail 25 April 2013, 7. The Star 25 April 2013. 8. Berita Harian 6 March 2004.

Fig. 3. Form in newspaper presentation campaigning.

\section{2) Describing form in online media}

All images in online media will present in color psychology, color tones and saturation are play important roles made in an artistic way and beautiful to look at.

Study also found, the direction and reflection are provided with form offered the opportunity to express different moods and an issue or problem. Tell different stories about the uniqueness of the picture posted big politician logo, having a dramatic impact on texture portrait, by originality in view angle, color, lighting, or composition full potential offers quality of photographs to capture in human judgment.

Strategies to be more effective of contrast to extreme instantly draw attention of drama, anxiety or tension of the person viewing the photograph. Size of an image has a good chance of affecting the photo ratings (See Fig. 4).

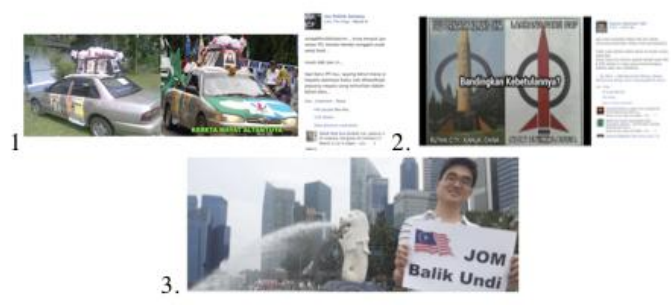

Source: Collection from Facebook 2013.

Fig. 4. Form in online media presentation campaigning.

\section{Medium}

\section{1) Describing medium in print media}

In print media, visual message are recoded in high resolution (large pixels) produces on $35 \mathrm{~mm}$ and 120 medium format cameras give much higher quality in visual campaign. The skills, techniques and equipments on the image-maker 
given angle of view more interesting scenes and position power on reading detail.

Represent vivid visual on colour or tone (black and white), size and proportion, versatile layout, and effect on text message (headline and caption) provided opportunity may guide the readers express issues in different mood or felling.

Information graphics, maps, drawings and logo labeled use in visual report make the storyline explained reality and more rational or logical (See Fig. 5).

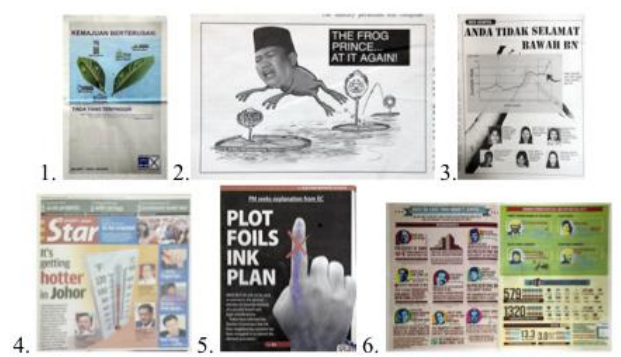

Source: 1. Utusan Malaysia 3 March 2008, 2. The Malay Mail 6 Mach 2004, 3. Suara Keadilan 17 February-12 March 2008, 4. The Star 10 April 2013, 5. New Straits Times 5 March 2008, 6. The Malay Mail 25 April 2013. 2008.

Fig. 5. Medium in newspaper campaign (The process of picture on issues address).

\section{2) Describing medium in online media}

Photo-sharing is a popular aspect of social media. As simple as taking the visual using on cell phone or compact camera (low-quality photos) as a way a amateur journalists made subjects of news articles and published a photograph.

Study also finds that size is not of importance. Posts aimed at providing information and awareness for individuals looking. Present in more creatively, update content and direct traffic to website can help shape and create psychological pleasing. With easy exposure also offering to access the issues information instantly.

More significantly the visual information responds faster better than text. The photo-sharing also opportunity for people to connect not only see the photograph story, but share the experience. The ability to comment and critique on image, writing about any feeling, memories, fantasy etc. may bring difference guidelines experience in reading popular of issues and increase political party brand (See Fig. 6).

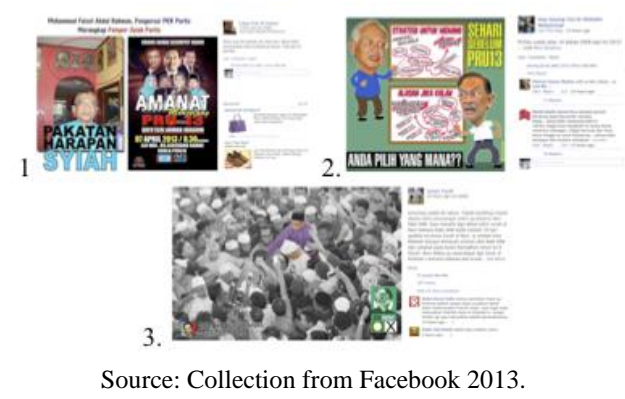

Fig. 6. Medium in online media campaign (The process of picture on issues address).

\section{Style}

\section{1) Describing style in print media}

Focus on storytelling in newsprint, study found the style on single and photomontage approach is used to serve reader's attention to read an article. Certain images, events and issues are presented in dynamic layouts, special column and advisement page to engage favorites view in way messages are reminder.

Importance issues or ideology parties are presenting in front page with big size and catching Headline to give a powerful in lead the reader attention.

Widely sharing on the portrait, group, the events, place or specific issues covered give the grammar of the content and function on news story more valuable and effect the viewer logically analyze or think about the issues and activities.

Textual message from shot caption, headline and slogan presentation also are use to enhance the effectiveness of the message (See Fig. 7).

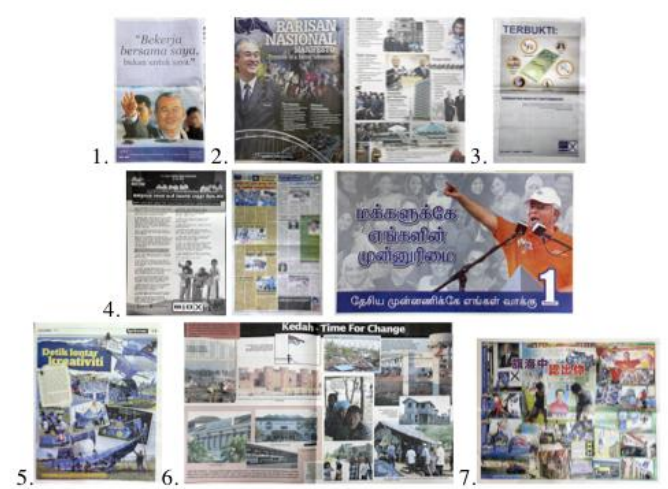

Source: 1.Utusan Malaysia 20 March 2004, 2. New Straits Times 26 February 2008, 3. Utusan Malaysia 27 February 2008, 4. Tamil Malaysia Nanban 25 April 2013, 5. Harian Metro 4 Mei 2013, 6.Harakah 1-15 March 2004, 7.China Press 23 April 2013.

Fig. 7. Presentation of style in print media campaigning.

\section{2) Describing style in online media}

Style on online media presentation more fashionable, highlight the subject or issues without limited of photograph use technology with online publishing, software, and evolving mobile device technology the best ways that citizens have the potential to observe and report more immediately and simply. By influence on the internet comment section, politicians also are simply tracked by how many fans.

Creative and unique picture more manipulation style. Using specific editing techniques are seen as superimpose, drawing technique etc. can present humor, gossip and attacking group for famous personalities and part of supporters closer to reality.

The power of the visual often strikes us more emotively than number (See Fig. 8).

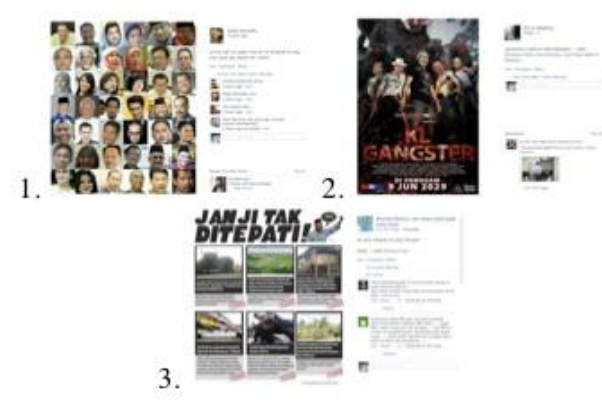

Source: Collection from Facebook

Fig. 8. Presentation of style in online media. 


\section{CONCLUSION}

Photography medium in media plays an important role in conveying the latest and the accurate information in public during election campaign. The role of photography as an instrument of persuasion in the news media during an election is the most effective weapon. This is because the media provided powerful channels of information between the political elite and the electorate. The needs and interests of the mass media can never be seen as political agents only, but it is also responsible for the development and prosperity of the country.

\section{REFERENCES}

[1] A. S. Hornby, Oxford Advance Learner's Dictionary of Current English, Oxford UK, Oxford University Press, pp. 409, 2010.

[2] D. S. N. T. Razak. (12 February 2012). Media Penentu Kejayaan Negara. [Online]. Available: http://www.utusan.com.my/utusan/info.asp?y=2012.

[3] Z. Zaherawati, Seminar Politik Malaysia, (Media: Ketelusan Dalam Pilihan Raya Malaysia Ke-12.), UiTM Shah Alam, University Publication Centre (UPENA), pp. 279, 2008.

[4] S. Iyengar, Media Politic: A Citizen's Guide, $2^{\text {nd }}$ Edition, New York. London: W.W. Norton \& Company, 2011.

[5] B. Warren, Photography, $2^{\text {nd }}$ Edition, New York, Thomson Learning, Inc., pp. 257-289, 2002.

[6] H. A. Mustaffa, Photography Its Significance Strands and Values in Education, UiTM Shah Alam, University Publication Centre, pp. 7-8, 2011.

[7] H. Joffe. (2008). The Power of Visual Material: Persuasion, Emotion and Identification. [Online]. pp. 84. Available: http://web.ebscohost.com/ehost.

[8] P. M. Lester, Visual Communication Images with Messages, $3^{\text {rd }}$ Edition, USA, Wadsorth/Thomson Learning, pp. 63, 2003.
[9] Mutharasan, Strategies of Anwar Ibrahim, Kuala Lumpur, Focus Media Enterprise, pp. 170-172, 2008.

[10] I. S. Arabi, Pilihan Raya Umum: Satu Perspektif Komunikasi Politik, Kuala Lumpur, Dewan Bahasa Dan Pustaka, pp. 68, 1993.

[11] T. Barret, Criticizing Photographs: An introduction to Understanding Images, New York: McGraw-Hill Companies, Inc., pp. 63-65, 2006.

[12] J. Sides, D. Swaw, M. Grossmann, and K. Lipsitz, Campaigns and Elections: Rule, Reality, Strategy, Choice, New York: W.W. Norton and Company, pp. 126, 2011.

[13] I. S. Arabi, Peranan Media Massa Dalam Pilihan Raya Umum Selangor Malaysia, IIUM Press, pp. 69-71, 2011

[14] S. Nathaniel, "Seeing is believing: The strategy behind campaign imagery and its impact on voters," ProQuest Dissertations and Theses, pp. 202, 2009.

[15] H. A. Mustaffa, "A critic study of photography education in Malaysia," Ph.D. Thesis, University Central England, Birmingham UK, pp. 17, 2006.

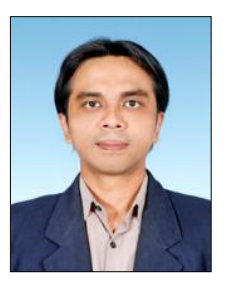

Md. Nagib Padil was born on May 1, 1976 in Muar, Johor, Malaysia. Now Ph.D. Candidate in Art and Design at University Technology Mara Shah Alam, Malaysia and has a master's degree in Visual Communication and New Media, University Technology Mara, Shah Alam, Selangor Malaysia and majoring in Advertising Photography (2006). He is a lecturer in Photography department at Faculty of Art and Design, University Technology Mara, Perak, Malaysia from 2006-Till Now. Among the publication has done as the title Photography on Billboard Advertisement and Visual Studio Lighting Tutorial (University Technology Mara, Perak, Malaysia) in 2010. He also active in writing on the topic of Photography Manipulation issues in Dunia Kamera magazine for 2013 in Malaysia.

Mr. Nagib also involved in several arts exhibitions committee and participants as International Arts, Culture and Education Exchange (2009 and 2010) at Srinakharinwirot University, Bangkok Thailand, Art Group Show Exhibition 'KAMI' at Penang Art Gallery, Malaysia (2007) and Photography Group show 'Imejan' at Badan Warisan, Kuala Lumpur, Malaysia in 2004 